\title{
ANALISIS MODEL ANTRIAN PADA LAYANAN TELLER UMUM BANK NAGARI CABANG UNIVERSITAS ANDALAS
}

\author{
GINAL RESKI, YUDIANTRI ASDI, MAIYASTRI \\ Program Studi S1 Matematika, \\ Fakultas Matematika dan Ilmu Pengetahuan Alam, Universitas Andalas, \\ Kampus UNAND Limau Manis Padang, Indonesia. \\ email : Ginareski11@gmail.com
}

\begin{abstract}
Abstrak. Analisis model antrian yang dilakukan pada layanan teller umum Bank Nagari Cabang Universitas Andalas Padang bertujuan untuk menganalisis proses antrian yang terjadi di bank tersebut. Antrian yang panjang atau waktu menunggu yang terlalu lama tentu akan merugikan bagi pihak nasabah ataupun pihak bank. Dari hasil analisis yang telah dilakukan diperoleh sistem antrian bagian teller umum Bank Nagari Cabang Universitas Andalas Padang mengikuti model (G/G/1) : $(\mathrm{GD} / \infty / \infty)$, tingkat kegunaan pelayanan $(\rho)$ sebesar 42,12 persen, peluang petugas tidak sedang melayani nasabah yaitu 0,5788, jumlah rata-rata nasabah yang diperkirakan dalam antrian adalah 5,3703 nasabah/menit, jumlah rata-rata nasabah yang diperkirakan dalam sistem adalah 5,7915 nasabah/menit dan waktu rata-rata menunggu yang diperkirakan dalam antrian adalah 29,2979 menit serta waktu rata-rata menunggu yang diperkirakan dalam sistem adalah 31,5957 menit.
\end{abstract}

Kata Kunci: Antrian, Model-model antrian, Pelayanan Bank

\section{Pendahuluan}

Banyaknya aktifitas keuangan di Bank Nagari cabang Universitas Andalas mengakibatkan proses antrian terjadi pada fasilitas pelayanan bank ini. Salah satunya pada fasilitas pelayanan teller umum yang hanya mempunyai satu jalur kedatangan, satu jalur pelayanan dan satu loket pelayanan. Saat seorang nasabah menginginkan layanan teller ini tidak jarang ditemui antrian yang panjang atau waktu menunggu yang terlalu lama. Hal ini tentu akan merugikan pihak nasabah karena banyak waktu yang terbuang untuk mengantri dan juga pihak bank karena akan menimbulkan pandangan yang kurang baik selanjutnya mengakibatkan berkurangnya kepercayaan nasabah untuk melakukan aktifitas keuangan pada bank tersebut, untuk itu perlu dilakukan analisis untuk melihat bagaimana proses antrian yang terjadi. Dari uraian tersebut, maka penulis menganggap masalah tersebut cukup menarik untuk dilakukan penelitian dengan topik yang dibahas adalah tentang model antrian yang digunakan pada layanan teller umum Bank Nagari cabang Universitas Andalas Padang. 


\section{Landasan Teori}

\subsection{Teori Antrian}

Teori Antrian (queueing theory) merupakan studi matematika dari antrian atau garis tunggu (waiting lines), yakni suatu garis tunggu dari pelanggan yang memerlukan layanan dari sistem pelayanan yang ada. Hal ini sering kita jumpai dalam kegiatan sehari-hari. Diantaranya menunggu di depan loket-loket pembayaran rekening, menunggu tiket kereta api, menunggu di pintu jalan tol. Selanjutnya pelanggan adalah konsumen yang datang, sedangkan loket merupakan tempat pelayanan. Rata-rata lamanya waktu untuk menunggu sangat bergantung pada rata-rata tingkat kecepatan layanan. Menunggu dapat terjadi karena kebutuhan akan layanan yang melebihi kapasitas pelayanan yang ada, sehingga mengakibatkan konsumen yang datang tidak segera terlayani [7].

Disiplin pelayanan adalah suatu aturan dalam memilih pelanggan dari barisan antrian untuk segera dilayani. Ada beberapa disiplin antrian yang biasa digunakan pada suatu sistem antrian, yaitu First come first out (FCFS), Last come first serve (LCFS), Service in random order (SIRO), dan Priority service (PS) [6]. Desain sarana pelayanan dapat diklasifikasikan dalam channel (saluran/jalur) dan phase (tahapan) yang akan membentuk suatu struktur yang berbeda-beda. ada beberapa jenis fasilitas yang dapat ditemui, di antaranya: Single channel single phase, Single channel multi phase, Multi channel single phase, Multi channel multi phase.

Pada distribusi kedatangan, biasanya digunakan distribusi peluang Poisson dimana kedatangan bersifat bebas dan tidak berpengaruh oleh kedatangan sebelum ataupun sesudahnya. Asumsi dari distribusi peluang Poisson ini adalah kedatangan pelanggan bersifat acak dan mempunyai tingkat kedatangan sebesar $\operatorname{Lamda}(\lambda)$. Sedangkan pada distribusi pelayanan, bentuk pelayanan ditentukan oleh waktu pelayanan yaitu waktu yang dibutuhkan untuk melayani pelanggan pada fasilitas pelayanan. Tingkat pelayanan dapat diberi simbol $\mu$ yang merupakan jumlah pelanggan yang dapat dilayani dalam satuan waktu. sedangkan rata-rata waktu yang dipergunakan untuk melayani pelanggan diberi simbol $\frac{1}{\mu}$ unit (satuan).

\subsection{Uji Kecocokan Distribusi}

Uji kecocokan distribusi (goodness of fit) dgunakan untuk mencocokan atau menguji tingkat kesesuaian antara distribusi serangkaian harga sampel observasi dengan suatu distribusi teoritis tertentu. Salah satu uji goodness of fit adalah uji Kolmogorov Smirnov. Adapun hipotesis yang digunakan adalah sebagai berikut.

$H_{0}$ : Sampel yang diambil berasal dari populasi distribusi tertentu.

$H_{1}$ : Sampel yang diambil tidak berasal dari populasi distribusi tertentu.

Dengan taraf signifikansi $=5 \%$. Selanjutnya akan dihitung statistik ujinya. Adapun statistik uji yang digunakan pada Uji Kolmogorov-Smirnov adalah

$$
D=\sup \left|S(x)-F_{0}(x)\right|
$$


dengan

$$
\begin{gathered}
S(x) \text { : proporsi nilai-nilai pengamatan data sampel. } \\
F_{0}(x) \text { : distribusi kumulatif dari distribusi yang dihipotesiskan. }
\end{gathered}
$$

Dengan taraf nyata $5 \%$, keputusan $H_{0}$ ditolak jika $D_{\text {hitung }}>D_{\text {tabel }}$ atau jika $P-$ Value $<\alpha$.

\subsection{Notasi Kendall}

Menurut [5], notasi baku dalam memodelkan sistem antrian atau dikenal sebagai notasi Kendall digunakan untuk merinci ciri dari suatu antrian. Terdapat beberapa unur dasar dari suatu model antrian, yaitu:

$$
(a / b / c):(d / e / f)
$$

dimana
$a$ : Distribusi kedatangan;
$b$ : Distribusi waktu pelayanan;
$c$ : Jumlah fasilitas pelayanan $c=1,2, \cdots$;
$d$ : Disiplin antrian, seperti :FCFS,LCFS, atau SIRO;
$e:$ Kapasitas sistem kedatangan;
$f$ : Sumber pemanggilan.

\subsection{Sitem Antrian Steady State}

Asumsi steady-state terpenuhi apabila $\lambda<\mu$ atau $\rho=\frac{\lambda}{\mu}<1$. Berdasarkan informasi tersebut dapat dihitung ukuran-ukuran kinerja antara lain jumlah pelanggan yang diperkirakan dalam sistem $\left(L_{s}\right)$, jumlah pelanggan yang diperkirakan dalam $\operatorname{antrian}\left(L_{q}\right)$, waktu menunggu yang diperkirakan dalam $\operatorname{sistem}\left(W_{s}\right)$, dan waktu menunggu yang diperkirakan dalam antrian $\left(W_{q}\right)[5]$.

\subsection{Model-model Antrian}

2.5.1. Model $(M / M / 1):(G D / \infty / \infty)$

Diasumsikan bahwa laju kedatangan tidak bergantung pada jumlah sistem tersebut, yaitu $\lambda_{n}=\lambda$ untuk semua $n$, dengan demikian pula pelayanan tunggal dalam sistem tersebut menyelesaikan pelayanan dengan kecepatan konstan, yaitu $\mu_{n}=\mu$ untuk semua $n$. Akibatnya, model ini memiliki kedatangan dan keberangkatan Poisson dengan mean $\lambda$ dan $\mu$. Didefinisikan probabilitas untuk $n$ pelanggan, yaitu [5]:

$$
P_{n}=\rho^{n} P_{0}, n=0,1,2, \cdots
$$

Jika mengasumsikan bahwa $\rho<1$, maka

$$
P_{0}\left(\frac{1}{1-\rho}\right)=1 \text { atau } P_{0}=1-\rho
$$


94 Ginal Reski dkk

Oleh karena itu diperoleh rumus umum berikut ini.

$$
P_{n}=(1-\rho) \rho^{n}, n=0,1,2, \cdots
$$

Selanjutnya akan diuraikan ukuran-ukuran kinerja sistem antrian model ini.

(a) Jumlah pelanggan yang diperkirakan dalam sistem $\left(L_{s}\right)$

$$
L_{s}=\frac{\rho}{1-\rho} .
$$

(b) Jumlah pelanggan yang diperkirakan dalam antrian $\left(L_{q}\right)$

$$
L_{q}=\frac{\rho^{2}}{1-\rho} .
$$

(c) Waktu menunggu yang diperkirakan dalam sistem $\left(W_{s}\right)$

$$
W_{s}=\frac{L_{s}}{\lambda}=\frac{1}{\mu(1-\rho)} .
$$

(d) Waktu menunggu yang diperkirakan dalam antrian $\left(W_{s}\right)$

$$
W_{q}=\frac{L_{q}}{\lambda}=\frac{\rho}{\mu(1-\rho)}
$$

2.5.2. Model $(G / G / 1):(G D / \infty / \infty)$

Ukuran-ukuran kinerja sistem pada model General ini mengikuti ukuran kinerja pada model $(M / M / 1):(G D / \infty / \infty)$, terkecuali untuk perhitungan jumlah pelanggan yang diperkirakan dalam antrian $L_{q}$. Rumus untuk mencari ukuran-ukuran kinerja pada model $(G / G / 1):(G D / \infty / \infty)$ adalah sebagai berikut [3].

(a) Jumlah pelanggan yang diperkirakan dalam $\operatorname{antrian}\left(L_{q}\right)$

$$
L_{q}=\frac{\rho^{2}}{1-\rho} P_{0} \frac{\mu^{2} v(t)+v\left(t^{\prime}\right) \lambda^{2}}{2},
$$

dimana

$$
\begin{gathered}
v(t)=\left(\frac{1}{\mu^{2}}\right)^{2}, \\
v\left(t^{\prime}\right)=\left(\frac{1}{\lambda^{2}}\right)^{2},
\end{gathered}
$$

dengan:

$$
\begin{gathered}
v(t) \text { : adalah varian dari waktu pelayanan. } \\
v\left(t^{\prime}\right) \text { : adalah varian dari jumlah kedatangan. }
\end{gathered}
$$

(b) Jumlah pelanggan yang diperkirakan dalam sistem $\left(L_{s}\right)$

$$
L_{s}=L_{q}+\rho .
$$

(c) Waktu menunggu yang diperkirakan dalam antrian $\left(W_{s}\right)$

$$
W_{q}=\frac{L_{q}}{\lambda} .
$$

(d) Waktu menunggu yang diperkirakan dalam sistem $\left(W_{s}\right)$

$$
W_{s}=\frac{L_{s}}{\lambda}
$$


2.5.3. Model $(M / G / 1):(G D / \infty / \infty)$

Pada model ini waktu pelayanan dijabarkan dengan sebuah distribusi umum (General) dengan mean $\mathrm{E}\{t\}$ dan varians var $\{t\}$. Anggaplah $\lambda$ adalah tingkat kedatangan di sebuah sarana dengan satu pelayan, dan diketahui $E\{t\}$ dan $\operatorname{var}\{t\}$ sebagai mean dan varians dari distribusi waktu pelayanan, dapat diperlihatkan dengan menggunakan analisis rantai probabilitas/Markov yang canggih bahwa jumlah rata-rata pelanggan yang diperkirakan dalam sistem berupa [10]:

(a) Jumlah pelanggan yang diperkirakan dalam antrian $\left(L_{q}\right)$

$$
L_{s}=\lambda E\{t\}+\frac{\left.\lambda^{2} E^{2}\{t\}+\operatorname{var}\{t\}\right) \lambda^{2}}{2(1-\lambda E\{t\}}
$$

(b) Jumlah pelanggan yang diperkirakan dalam sistem $\left(L_{s}\right)$

$$
L_{q}=L_{s}-\lambda E\{t\}
$$

(c) Waktu menunggu yang diperkirakan dalam antrian $\left(W_{s}\right)$

$$
W_{q}=\frac{L_{q}}{\lambda} .
$$

(d) Waktu menunggu yang diperkirakan dalam sistem $\left(W_{s}\right)$

$$
W_{s}=\frac{L_{s}}{\lambda} .
$$

\section{Metode Penelitian}

Data yang digunakan dalam penelitian ini merupakan data contoh yang diperoleh melalui pengamatan langsung yang dilakukan di Bank Nagari cabang Universitas Andalas kota Padang. Selanjutnya pengamatan dilakukan selama 5 hari yaitu pada tanggal 8, 9, 10, 11, 12 Oktober 2018 mulai pukul 08.00 - 11.30 WIB. Adapun langkah-langkah penelitian dan analisis data yang dilakukan adalah:

(1) Menghitung data jumlah kedatangan nasabah setiap 15 menit dan waktu pelayanan masing-masing nasabah.

(2) Melihat apakah data memenuhi kondisi steady state.

(3) Melakukan uji kecocokan distribusi untuk mengetahui distribusi kedatangan nasabah menggunakan uji Kolmogorov-Smirnov.

(4) Menentukan model antrian yang sesuai berdasarkan distribusi jumlah kedatangan dan waktu pelayanan nasabah oleh teller umum.

(5) Menentukan ukuran kinerja sistem antrian.

(6) Mengambil kesimpulan dari model yang didapatkan.

\section{Pembahasan}

\subsection{Ukuran Steady-State kinerja Layanan Teller Umum}

Apabila nilai kegunaan fasilitas pelayanan pada loket antrian ini kurang dari satu maka ukuran kinerja sistem akan berjalan stabil atau dapat diartikan bahwa ratarata kedatangan nasabah lebih kecil dari pada rata-rata nasabah yang dapat dilayani. Dari data dapat dilihat bahwa jumlah kedatangan nasabah pada bagian 
teller umum adalah 220 0rang. Terdapat 80 data diperoleh dari jumlah interval setiap 15 menit selama waktu pengamatan. Oleh karena itu, berdasarkan data tersebut diperoleh tingkat kedatangan nasabah () yaitu :

$$
\lambda=\frac{220}{80}=2,75 \text { nasabah } / 15 \text { menit }
$$

atau 0,1833 nasabah/menit.

Selanjutnya juga diperoleh jumlah waktu pelayanan nasabah adalah 8 jam 25 menit 30 detik atau 505,5 menit dengan jumlah nasabah yang telah dilayani adalah 220 orang maka rata-rata waktu pelayanan pada bagian teller umum adalah 2,2978 menit/nasabah sehingga diperoleh rata-rata nasabah yang dapat dilayani $(\mu)$ adalah:

$$
\mu=\frac{1}{2,2978}=0,4352 \text { nasabah } / \text { menit. }
$$

Dengan demikian didapatkan nilai tingkat kegunaan pelayanan oleh bagian teller umum dengan jumlah loket $(c)=1$ adalah :

$$
\rho=\frac{\lambda}{c \times \mu}=\frac{0,1833}{1 \times 0,4352}=0,4212 .
$$

Karena nilai dari tingkat kegunaan pelayanan $(\rho)$ adalah $0,4212<1$, maka dapat disimpulkan bahwa sistem antrian oleh teller umum telah memenuhi kondisi steadystate dengan tingkat kesibukan pelayanan sebesar 42,12 persen. Dari nilai tersebut diketahui bahwa tidak terjadi antrian yang cukup padat pada bagian teller ini.

\subsection{Uji Distribusi Kedatangan Nasabah}

Uji distribusi kedatangan nasabah yang digunakan adalah uji Kolmogorov-Smirnov. Uji ini digunakan untuk menganalisa apakah distribusi jumlah kedatangan nasabah mengikuti distribusi Poisson, dengan hipotesis:

$H_{0}$ : Jumlah kedatangan nasabah ke bagian teller umum berdistribusi Poisson, $H_{1}$ : Jumlah kedatangan nasabah ke bagian teller umum tidak berdistribusi Poisson.

Berdasarkan hasil pengolahan data dengan menggunakan SPSS, diperoleh nilai $D_{\text {hitung }}$ adalah sebesar 0,174 . Selanjutnya nilai $D_{\text {tabel }}$ untuk n $=80$ dan taraf nyata $\alpha=5$ persen adalah 0,1520 . Karena nilai $D_{\text {hitung }}>D_{\text {tabel }}$ maka dapat diputuskan tolak $H_{0}$ artinya pada taraf nyata 5 persen jumlah kedatangan nasabah ke bagian teller umum tidak berdistribusi Poisson.

\subsection{Uji Distribusi Waktu Pelayanan Nasabah}

Uji distribusi waktu pelayanan nasabah yang digunakan adalah uji KolmogorovSmirnov. Uji ini digunakan untuk menganalisa apakah distribusi waktu pelayanan nasabah oleh teller mengikuti distribusi Eksponensial, dengan hipotesis:

$H_{0}$ : Waktu pelayanan nasabah oleh teller umum berdistribusi Eksponensial,

$H_{1}$ : Waktu pelayanan nasabah oleh teller umum tidak berdistribusi Eksponensial. 
Berdasarkan hasil pengolahan data dengan menggunakan SPSS, diperoleh nilai $D_{\text {hitung }}$ adalah sebesar 0,255 . Selanjutnya nilai $D_{\text {tabel }}$ untuk $\mathrm{n}=220$ dan taraf nyata $\alpha=5$ persen adalah 0,0917 . Karena nilai $D_{\text {hitung }}>D_{\text {tabel }}$ maka dapat diputuskan tolak $H_{0}$ artinya pada taraf nyata 5 persen waktu pelayanan nasabah oleh teller umum tidak berdistribusi Eksponensial.

\subsection{Model Sistem Antrian Bagian Teller Umum}

Berdasarkan hasil analisis ukuran steady-state, uji distribusi jumlah kedatangan dan waktu pelayanan nasabah oleh teller umum dapat dikatakan bahwa sistem antrian bagian teller umum mengikuti model $(G / G / 1):(G D / \infty / \infty)$ artinya distribusi kedatangan nasabah tidak berdistribusi Poisson (general), distribusi waktu pelayanan nasabah tidak berdistribusi Eksponensial (general), jumlah loket yang beroperasi adalah satu, disiplin pelayanan adalah FCFS (first come first served), serta jumlah pelayanan maksimum dan sumber kedatangan bersifat tak berhingga $(\infty)$.

\subsection{Ukuran Kinerja Sistem Antrian Bagian Teller Umum}

Berdasarkan hasil perhitungan sebelumnya mengenai model $(G / G / 1):(G D / \infty / \infty)$ pada sistem antrian bagian teller maka untuk menghitung ukuran kinerja sistem antriannya menggunakan perhitungan model tersebut. Diketahui tingkat kedatangan dan tingkat pelayanan antrian yaitu:

$$
\begin{aligned}
\lambda & =0,1833 \text { nasabah } / \text { menit } \\
\mu & =0,4352 \text { nasabah } / \text { menit } \\
c & =1 \text { petugas. }
\end{aligned}
$$

maka peluang terdapat 0 nasabah dalam sistem $\left(P_{0}\right)$ yaitu :

$$
P_{0}=1-\rho=1-0,4212=0,5788 .
$$

Jadi peluang terdapat 0 nasabah dalam sistem atau peluang dimana petugas tidak sedang melayani seorang nasabah adalah 0,5788. Selanjutnya akan dicari rata-rata jumlah nasabah dalam antrian $\left(L_{q}\right)$ dengan menggunakan rumus sebagai berikut:

$$
L_{q}=5,3703 \text { nasabah/menit. }
$$

Berdasarkan perhitungan di atas diperoleh jumlah rata-rata nasabah menunggu dalam antrian bagian teller umum sebesar 5,3703 nasabah/menit. Selanjutnya dapat dihitung rata-rata jumlah nasabah dalam sistem $\left(L_{s}\right)$ dengan rumus sebagai berikut:

$$
L_{s}=5,7915 \text { nasabah/menit. }
$$

Dari hasil perhitungan di atas diperoleh bahwa rata-rata jumlah nasabah dalam sistem $\left(L_{s}\right)$ sebesar 5,7915 nasabah/menit. Kemudian akan dihitung waktu ratarata yang dapat dihabiskan nasabah untuk menunggu dalam antrian $\left(W_{q}\right)$, dengan rumus sebagai berikut:

$$
W_{q}=29,2979 \text { menit. }
$$


Berdasarkan hasil perhitungan di atas maka diperoleh waktu rata-rata nasabah menunggu dalam antrian sebesar 29,2979 menit. Selanjutnya akan dihitung waktu rata-rata yang dapat dihabiskan nasabah untuk menunggu dalam sistem $\left(W_{s}\right)$ dengan rumus sebagai berikut:

$$
W_{s}=31,5957 \text { menit. }
$$

Dari perhitungan di atas maka diperoleh bahwa waktu rata-rata nasabah yang menunggu dalam sistem sebesar 31,5957 menit.

\section{Kesimpulan}

Berdasarkan hasil pembahasan yang telah disajikan, maka dapat disimpulkan bahwa sistem antrian bagian teller umum Bank Nagari cabang Universitas Andalas Padang mengikuti model $(G / G / 1):(G D / \infty / \infty)$. Model ini adalah model dengan distribusi kedatangan nasabah tidak berdistribusi Poisson (general) dan distribusi waktu pelayanan nasabah tidak berdistribusi Eksponensial (general). Selanjutnya, jumlah loket yang beroperasi adalah satu, disiplin pelayanan adalah FCFS (first come first served), serta jumlah pelayanan maksimum dan sumber kedatangan bersifat tak berhingga $(\infty)$. Dari hasil analisis model antrian pada layanan teller umum Bank Nagari cabang Universitas Andalas Padang, didapatkan ukuran-ukuran kinerja sistem antriannya yaitu umtuk peluang terdapatnya 0 nasabah dalam sistem $\left(P_{0}\right)$ adalah 0,5788 , jumlah rata-rata nasabah yang diperkirakan dalam antrian $\left(L_{q}\right)$ adalah 5,3703 nasabah/menit, jumlah rata-rata nasabah yang diperkirakan dalam sistem $\left(L_{s}\right)$ adalah 5,7915 nasabah/menit dan waktu rata-rata menunggu yang diperkirakan dalam antrian $\left(W_{q}\right)$ adalah 29,2979 menit serta waktu rata-rata menunggu yang diperkirakan dalam sistem $\left(W_{s}\right)$ adalah 31,5957 menit.

\section{Daftar Pustaka}

[1] Bronson, R. 1983. Theory and Problems of Operations Research, Schaum's Outline series. Mc. Graw-Hill, Singapura.

[2] Heizer, J dan B. 2005. Operations Managament. Salemba Empat,Jakarta.

[3] Kakiay, T.J. 2004. Dasar Teori Antrian untuk Kehidupan Nyata. Andi,Yogyakarta.

[4] Kamus Bisnis Bank. Definisi Teller. Sumber : http:/www.mediabpr.com/kamus-bisnis-bank/teller.arspx.

[5] Mulyono, S. 2004. Riset Operasi. FE-UI, Jakarta.

[6] P.A Purina, Sugito dan A. Hoyyi. 2014. Analisis Antrian Pada Layanan Pengurusan Paspor di Kantor Imigrasi Kelas I Semarang. Jurnal Gaussian. 3: 801 $-810$.

[7] Ross, S.M.2009. Introduction to Probability Models. Academic Press, New York.

[8] Sinalungga, S. 2008. Pengantar Teknik Industri. Graha Ilmu, Yogyakarta.

[9] Subagyo, P.1995. Dasar-Dasar Operations Research. BPPT, Yogyakarta.

[10] Taha, H. A. 1996. Riset Operasi Jilid 2. Binarupa Aksara, Jakarta. 